\title{
Inhibition of Amyloid-like Fibril Formation of Trypsin by Red Wines
}

\author{
Márta Kotormán ${ }^{* a}$, Phanindra Babu Kasi ${ }^{\mathrm{a}}$, László Halász $^{\mathrm{a}, \mathrm{b}}$ and Attila Borics ${ }^{\mathrm{b}}$
}

\begin{abstract}
${ }^{a}$ Department of Biochemistry and Molecular Biology, Faculty of Science and Informatics, University of Szeged, Közép fasor 52, H-6726 Szeged, Hungary; ${ }^{b}$ Laboratory of Chemical Biology, Biological Research Centre of Hungarian Academy of Sciences, Temesvári krt. 62, H-6726 Szeged, Hungary
\end{abstract}

\begin{tabular}{|c|c|}
\hline & $\begin{array}{l}\text { Abstract: The aim of the present study was to examine the potential role and applicability of dietary } \\
\text { supplements in reducing the risk of develonment of amyloid diseases associated with the gastrointes- }\end{array}$ \\
\hline A R T I C L E H IS T ORY & tinal tract, such as type II diabetes. Trypsin, a well-known serine protease was used as a model pro \\
\hline Received: December 8, 2016 & trypsin was studied in vitro, in aqueous ethanol, at $\mathrm{pH} 7.0$. Turbidity measurements, aggregation \\
\hline Revised: February 8, 2017 & kinetics experiments, Congo red binding assays and electronic circular dichroism spectroscopic \\
\hline Accepted: February 8, 2017 & measurements were used to follow the aggregation process in the presence or absence of various red \\
\hline $\begin{array}{l}\text { DOI: } 10.2174 / 0929866524666170214 \\
\text { 125847 }\end{array}$ & $\begin{array}{l}\text { wines. The results suggest that red wines effectively inhibit the formation of amyloid-like fibrils of } \\
\text { trypsin and the inhibitory effect is dose-dependent. The extent of inhibition was found to be propor- } \\
\text { tional to the total concentration of phenolic compounds. }\end{array}$ \\
\hline
\end{tabular}

Keywords: Amyloid-like fibrils, electronic circular dichroism, congo red, natural polyphenols, red wine, trypsin.

\section{INTRODUCTION}

Amyloid formation might be a general property of the polypeptide backbone as all proteins can form longunbranched, $\beta$-sheet rich amyloid fibrils in vitro under appropriate conditions [1-2]. There are striking similarities in the aggregation behavior of different peptides and proteins. Unfolded or partially unfolded proteins associate with each other to form small, soluble aggregates that undergo further assembly into protofibrils or protofilaments. These structures are commonly short, thin, sometimes curved, fibrillar species that are presumed to assemble into mature fibrils. Experiments in vitro indicate that the formation of such species is generally characterized by a lag phase, followed by a period of rapid growth. This phenomenon is associated with common and highly debilitating diseases. An increasing number of disorders, including Alzheimer's and Parkinson's diseases, spongiform encephalopathy and type II diabetes, are directly associated with the deposition of such aggregates in brain, heart and spleen tissue. Amyloid diseases predominantly involve the aggregation of specific proteins, such as the prion protein or the amyloid $\beta$-peptide, but fibrils can be formed by many other peptides and proteins [3]. Natural phenolic compounds, a long family of plant substances, are one of the most actively investigated categories of potential amyloid inhibitors [4-6]. More than 8,000 plant polyphenols are currently known and more than 4,000 flavonoids have been identified among them [7]. Red wine represents a rich source of polyphenols such as flavonoids (flavanol

*Address correspondence to this author at the Department of Biochemistry and Molecular Biology, Faculty of Science and Informatics, University of Szeged, H-6726 Szeged, Középfasor 52, Hungary; Tel: +36-62-544543; Fax:+36-62-544887; E-mail: kotorman@expbio.bio.u-szeged.hu monomers, condensed tannins, flavonols, anthocyanins) as well as non-flavonoids (hydroxycinnamates, benzoic acids, hydrolyzable tannins and stilbenes (resveratrol)) [8]. Resveratrol, a polyphenolic red wine constituent, inhibits $A \beta 42$ fibril formation and islet amyloid polypeptide aggregation in a dose-dependent manner [9-10]. The inhibitory effect of flavone derivatives is dependent on the number and position of hydroxyl groups around the flavone backbone [11]. The position of phenolic hydroxyl moieties on the aromatic rings is a major determinant of the potent anti-aggregation effect, while the number of hydroxyl groups is less important [12]. Natural phenolic and polyphenolic substances stabilize native states, or remodel and inactivate toxic amyloid oligomers [4]. Several observations suggest that polyphenols inhibit amyloid fibril formation through specific aromatic interactions with the amyloidogenic core [13]. Aromatic rings of polyphenolic compounds and the aromatic residues present in proteins may associate via $\pi-\pi$ stacking interactions [14]. The hydrophobic and/or aromatic character of these compounds contributes significantly to the antiamyloidogenic effect, whereas the antioxidative potency relates mostly to the destabilization of fibrils [15]. Studies have shown that the presence of vicinal dihydroxyphenyl moieties, irrespective of their position in the aromatic rings, play a key role in the inhibitory property of polyphenols [1617]. Non-flavonoids showed higher anti-aggregation activity than flavonoids. Polyphenols containing a higher number of aromatic rings, hydroxyl and keto groups and possess a high degree of planarity, have the largest inhibititory activity [18]. A structure-function relationship study suggested that the presence of at least two phenolic rings with two to six atomlong linkers, along with a minimum number of three hydroxyl groups on the aromatic rings, are essential for effi- 
cient inhibition exerted by polyphenols [5]. The mechanism of inhibition of amyloid formation is not identical for all natural polyphenols. Some inhibit the formation of oligomers, but promote fibril formation, others inhibit the formation of fibrils, but not oligomers, and there are others, which inhibit both. Other polyphenols redirect amyloid fibrils from fibrillogenic forms to nonfibrillogenic oligomers [19]. Polyphenols induce conformational changes in the oligomer aggregate. These changes disrupt $\mathrm{H}$-bonds and perturb the amyloid aggregate. Polyphenol molecules separate the $\beta$-sheets, which leads to a loosely packed structure. Hbonding capacity of polyphenols is responsible for this behavior [20]. Flavonoids, phenols in particular, represent an important component of a normal human diet. Elevated intake of dietary polyphenols might be relevant to the prevention of amyloidosis. Nutraceutical strategies might become a way to reduce the risk of certain amyloid diseases [19, 21]. Many drugs used today are natural products or derivatives of natural products [22-23].

Earlier we have demonstrated that phenylmethylsulfonyl-trypsin (PMS-trypsin) forms amyloid-like fibrils in $60 \%(\mathrm{v} / \mathrm{v})$ ethanol $/ 10 \mathrm{mM}$ phosphate buffer $(\mathrm{PBS})$ at $\mathrm{pH}=$ 7.0 [24]. Here, we report that various red wines inhibit the formation of amyloid-like fibrils of PMS-trypsin dosedependently.

\section{MATERIALS AND METHODS}

\subsection{Materials}

Bovine pancreas trypsin (EC 3.4.21.4), gallic acid and $N$ benzoyl-L-arginine ethyl ester (BAEE) were purchased from Sigma-Aldrich Company (Budapest, Hungary). FolinCiocalteu's phenol reagent was the product of Merck (Darmstadt, Germany). Red wines were purchased from commercially sources: La Bonita Cabernet Franc semi-sweet and Pincegyöngye Édes Vörös sweet red wines bottled by Helibor Ltd., H-6070 Izsák; Transdanubian Merlot sweet red wine, bottled by Szent Imre Wine-cellar Ltd., H-6223 Soltszentimre; La Fiesta Kékfrankos semi-sweet red wine, bottled by Grape-Vine Ltd., H-6120 Kiskunmajsa; Egri bikavér 2012 dry red wine, bottled by Ostoros-Novaj Bor Co., H-3327 Novaj; Portugieser 2014 dry red wine, bottled by Dolium Wine-cellar Ltd., H-7773 Villány.

\subsection{General Methods}

Trypsin concentration was determined based on the UV absorbance of the constituent aromatic and cystine residues at $280 \mathrm{~nm}$, using a calibration curve measured for trypsin in the $0-1 \mathrm{mg} / \mathrm{mL}$ concentration range. Spectroscopic samples have been corrected for respective solvent backgrounds in all experiments where applicable.

\subsection{Assay of Enzyme Activity}

Trypsin activity, with BAEE as a substrate, was determined using the method of Schwert and Takenaka [25]. The absorption increase at $253 \mathrm{~nm}$ was measured in a $3 \mathrm{~mL}$ reaction mixture, containing $46.7 \mathrm{mM}$ Tris $/ \mathrm{HCl}(\mathrm{pH} 8.0)$ and 0.9 $\mathrm{mM}$ BAEE. The reaction was started by the addition of 20 $\mu \mathrm{L}$ enzyme sample $(0.15 \mathrm{mg} / \mathrm{mL})$.

\subsection{Trypsin Modification with Phenylmethylsulfonyl Fluoride (PMSF)}

Chemical modification with PMSF inactivates trypsin irreversibly. Thus the autolysis of enzyme at $\mathrm{pH}=7.0$ does not affect the experiments. Solutions of $8.4 \mu \mathrm{L}$ PMSF (100 $\mathrm{mM})$ in 2-propanol and $20 \mu \mathrm{L}$ trypsin $(50 \mathrm{mg} / \mathrm{mL})$ in 0.001 $\mathrm{M} \mathrm{HCl}$ were added to $2 \mathrm{~mL} 0.05 \mathrm{M} \mathrm{PBS}(\mathrm{pH}=7.0)$ at $24{ }^{\circ} \mathrm{C}$ while the solution was stirred. During the procedure identical amounts of reactants were added four times, repeatedly to the solution. The enzyme sample was incubated for $30 \mathrm{~min}$. The reaction mixture was then filtered on a Sephadex G-25 column in 0.05 M PBS $(\mathrm{pH}=7.0)$, to remove the unreacted inhibitor molecules. The degree of conversion was determined by enzymatic activity assays, of which results indicated that $95 \%$ of the trypsin had been modified.

\subsection{Turbidity Measurements}

In order to estimate the amount of fibrillar material, turbidity of PMS-trypsin solutions was monitored by UV-vis spectrophotometry at $350 \mathrm{~nm}$ and $24{ }^{\circ} \mathrm{C}$, using a quartz cuvette of $10 \mathrm{~mm}$ path length. Turbidity experiments were performed in $0.13 \mathrm{mg} / \mathrm{mL}$ solutions of PMS-trypsin in $60 \%$ $(\mathrm{v} / \mathrm{v})$ ethanol/10 mM PBS $(\mathrm{pH}=7.0)$ after $24 \mathrm{~h}$ incubation in the presence or absence of red wines at a 50 -fold final dilution.

\subsection{Determination of Total Phenolic Content}

The total phenolic content of red wine samples was determined utilizing the Folin-Ciocalteu reagent and the spectrophotometric method of Waterhouse [26]. For calibration, gallic acid solutions of different concentrations $(0-50 \mathrm{mg} / \mathrm{L})$ were used. The total phenolic content was expressed as $\mathrm{mg}$ gallic acid equivalents (GAE) per liter of red wine. The data presented are the average of three measurements.

\subsection{Aggregation Kinetics}

Aggregation experiments were performed in $60 \%(\mathrm{v} / \mathrm{v})$ ethanol $/ 10 \mathrm{mM}$ PBS $(\mathrm{pH}=7.0)$ at $0.13 \mathrm{mg} / \mathrm{mL}$ PMS-trypsin concentration and various concentrations of red wine. The increase of UV absorption at $350 \mathrm{~nm}$, indicative of the presence of large aggregated particles, was followed for $30 \mathrm{~min}$ at $24{ }^{\circ} \mathrm{C}$ and $\mathrm{pH} 7.0$.

\subsection{CR Binding}

Absorption spectra of Congo red (CR) were recorded in the range of $400-600 \mathrm{~nm}$ using a $10 \mathrm{~mm}$ path length quartz cuvette. Samples were prepared at a protein concentration of $0.285 \mathrm{mg} / \mathrm{mL}$. Two hundred $\mu \mathrm{L}$ 1-day-aged PMS-trypsin samples in $60 \%(\mathrm{v} / \mathrm{v})$ ethanol, in the absence or presence of Egri bikavér, were vortexed with $800 \mu \mathrm{L}$ of a solution containing $4.9 \mu \mathrm{M} \mathrm{CR}, 5 \mathrm{mM}$ PBS and $150 \mathrm{mM} \mathrm{NaCl}(\mathrm{pH} 7.0)$ and was incubated at room temperature for $15 \mathrm{~min}$ before the measurements. Difference spectra were obtained by subtracting the spectra of CR alone and PMS-trypsin alone from spectra of solutions containing both PMS-trypsin and CR. 


\subsection{ECD Measurements}

Electronic circular dichroism (ECD) measurements were carried out using a Jasco J-815 spectropolarimeter. Spectra were recorded in the range of $185-260 \mathrm{~nm}$ in a $1 \mathrm{~mm}$ path length cell at $24{ }^{\circ} \mathrm{C}$. PMS-trypsin was dissolved in $60 \%$ $(\mathrm{v} / \mathrm{v})$ ethanol/10 mM PBS $(\mathrm{pH} 7.0)$ at a concentration of 0.15 $\mathrm{mg} / \mathrm{mL}$. Red wine was contained in the samples at a 50 -fold dilution.

\section{RESULTS AND DISCUSSION}

PMS-trypsin amyloid-like fibrils were prepared in aqueous ethanol according to our previous report [24]. To determine whether red wines affect fibril formation of PMStrypsin, samples were incubated in aqueous ethanol at $\mathrm{pH}$ 7.0, in the presence and absence of different red wines. Aggregation of PMS-trypsin can be monitored by turbidity measurements. An increase in the UV absorbance at $350 \mathrm{~nm}$ indicates a greater degree of aggregation due to an increase in the scattering of light by aggregated particles [16]. In the absence of red wines, higher absorbance values were observed indicating higher degree of turbidity and that red wines have the ability to effectively inhibit PMS-trypsin fibril formation in vitro (Figure 1). These experiments revealed that the greatest effect was exerted by the red wine Egri bikavér in $60 \%(\mathrm{v} / \mathrm{v})$ ethanol/10 mM PBS $(\mathrm{pH}=7.0)$. The absorption at $350 \mathrm{~nm}$ decreased to $51.9 \%$ relative to the reference sample after incubation for $24 \mathrm{~h}$ in the presence of diluted Egri bikavér.

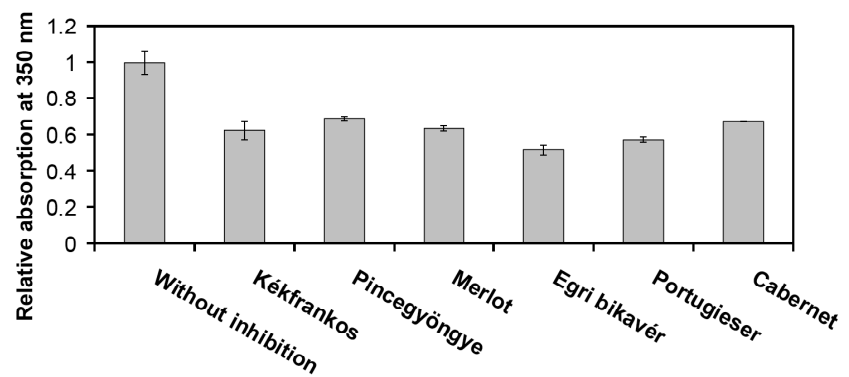

Figure 1. Turbidity changes of PMS-trypsin at $24{ }^{\circ} \mathrm{C}$ in $60 \%(\mathrm{v} / \mathrm{v})$ ethanol/10 mM PBS $(\mathrm{pH}=7.0)$, monitored via the absorption at $350 \mathrm{~nm}$ after incubation for $24 \mathrm{~h}$ in the presence of various red wines at 50 -fold dilution. The protein concentration was 0.13 $\mathrm{mg} / \mathrm{mL}$.

The total concentration of phenolic compounds of various red wines varied from 1,053 to 2,354 $\mathrm{mg} \mathrm{GAE/L} \mathrm{(Figure}$ 2). The degree of inhibition was found to be proportional to the total phenolic content. Figure 3 illustrates that red wine led to a dose-dependent decrease in the absorption.

$\mathrm{CR}$ is a planar, hydrophobic, diazo dye, which binds to the $\beta$-sheet of amyloid and amyloid-like fibrils selectively, therefore it is a commonly used agent to detect amyloid fibrils. Binding of CR to amyloid generally results in an increase and a characteristic red shift (from $490 \mathrm{~nm}$ to $540 \mathrm{~nm}$ ) of light absorption [27-28]. A moderate red shift of the absorption maximum (from $490 \mathrm{~nm}$ to $510 \mathrm{~nm}$ ) was observed

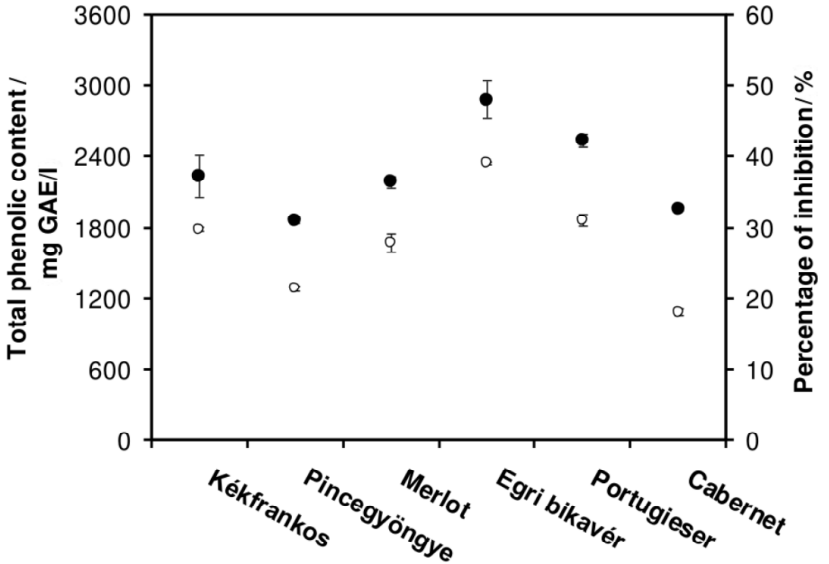

Figure 2. Inhibition of amyloid-like fibril formation as a function of total phenolic content. Percentage of inhibition in $60 \%(\mathrm{v} / \mathrm{v})$ ethanol $(\bullet)$, total phenolic content $(\circ)$. Red wines were diluted 50fold in $60 \%(\mathrm{v} / \mathrm{v})$ ethanol/10 $\mathrm{mM}$ PBS $(\mathrm{pH}=7.0)$. The protein concentration was $0.13 \mathrm{mg} / \mathrm{mL}$.

in the visible spectra of $\mathrm{CR}$ in the presence of PMS-trypsin in $60 \%(\mathrm{v} / \mathrm{v})$ ethanol/10 mM PBS $(\mathrm{pH}=7.0)$ (Figure 4). Difference spectra indicate spectral changes of CR upon binding to PMS-trypsin amyloid fibrils in the absence or presence of 25 to 250 -fold diluted red wine, Egri bikavér. This suggests that the aggregates have amyloid-like properties in $60 \%(\mathrm{v} / \mathrm{v})$ ethanol/10 mM PBS $(\mathrm{pH}=7.0)$ and the active components of Egri bikaver inhibit the formation of amyloid fibrils dose-dependently.

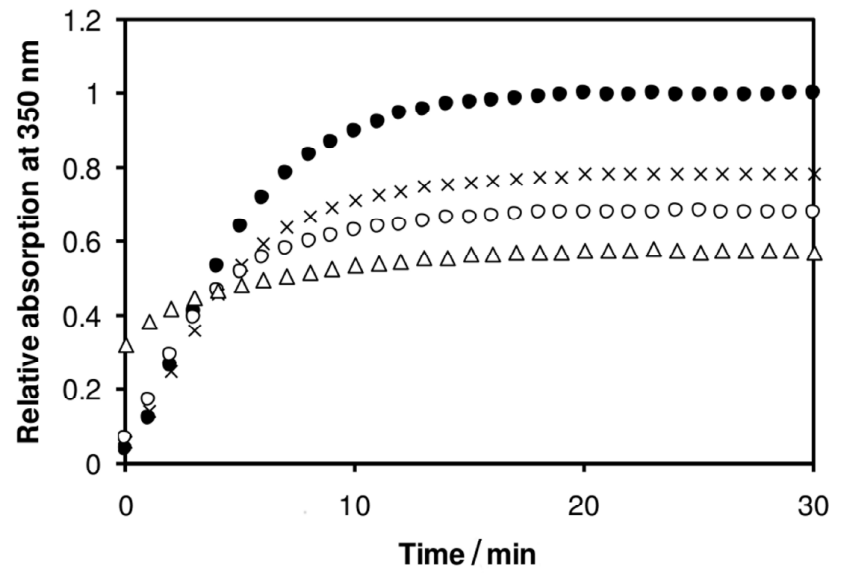

Figure 3. Kinetics of aggregation of PMS-trypsin without red wine $(\bullet)$ in $60 \%(\mathrm{v} / \mathrm{v})$ ethanol/10 $\mathrm{mM}$ PBS $(\mathrm{pH}=7.0)$, or in the presence of Merlot wine diluted 50- $(\Delta), 1000-(\circ)$, or 4000-fold (x), monitored via the time-dependent increase of $U V$ absorption at $350 \mathrm{~nm}$, at $0.13 \mathrm{mg} / \mathrm{mL}$ protein concentration.

Changes in the secondary structure of PMS-trypsin were followed by ECD measurements. ECD spectra of PMStrypsin in $60 \%(\mathrm{v} / \mathrm{v})$ ethanol/10 mM PBS $(\mathrm{pH}=7.0)$, measured in the presence or in the absence of 50-fold diluted Egri bikavér are shown in Figure 5. Measurements were carried 


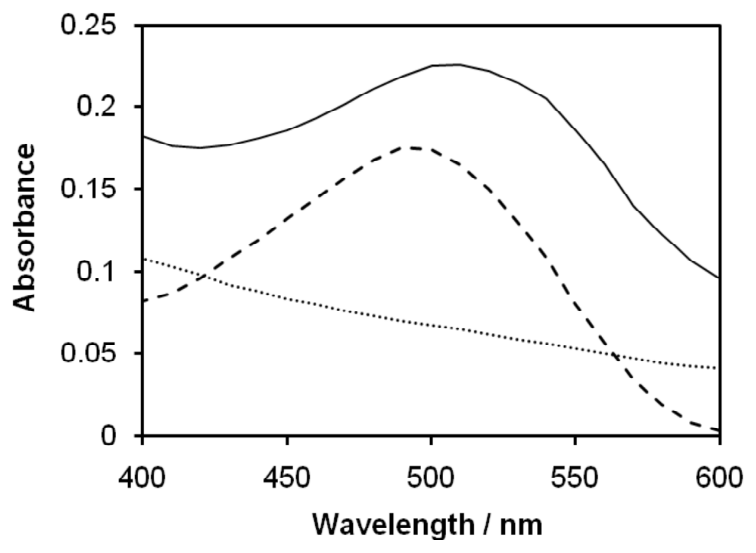

A

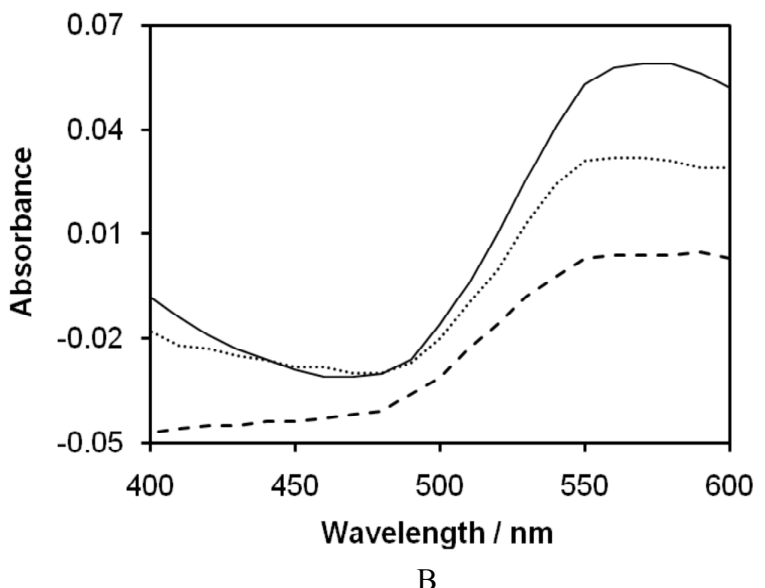

Figure 4. Visible absorption spectra of PMS-trypsin stained with $\mathrm{CR}$ in $60 \%(\mathrm{v} / \mathrm{v})$ ethanol/10 $\mathrm{mM} \mathrm{PBS}(\mathrm{pH}=7.0)$ : PMS-trypsin $+\mathrm{CR}(\mathbf{A}$, solid line), CR alone (A, dashed line), PMS-trypsin alone (A, dotted line) and difference spectra in $60 \%(\mathrm{v} / \mathrm{v})$ ethanol/10 $\mathrm{mM} \mathrm{PBS}(\mathrm{pH}=7.0)$ without red wine (B, solid line) or in the presence of Egri bikavér wine in 25- (B, dashed line) and 250-fold (B, dotted line) final dilution. Spectra were recorded at $3.9 \mu \mathrm{M}$ and $57 \mu \mathrm{g} / \mathrm{mL}$ dye and protein concentrations, respectively.

out by placing the cuvette either in the middle of the sample compartment or next to the detector. For clear, homogenous samples the two measurements shall provide identical results. Remarkable change in the intensity and a blue shift of the $217 \mathrm{~nm}$ minimum was observed in the absence of red wine, upon moving the cuvette from the middle of the sample compartment towards the detector, indicating aggregated particles in the sample. Light dispersion of the sample was significantly decreased by the addition of 50 -fold diluted Egri bikavér wine, suggesting that a lower amount of aggregates is present compared to the sample not containing the additive. It was shown previously, that high concentrations of ethanol promote structural transitions of PMS-trypsin, resulting in an increase of $\beta$-sheet structure of the protein [24]. Such structural features were not changed remarkably

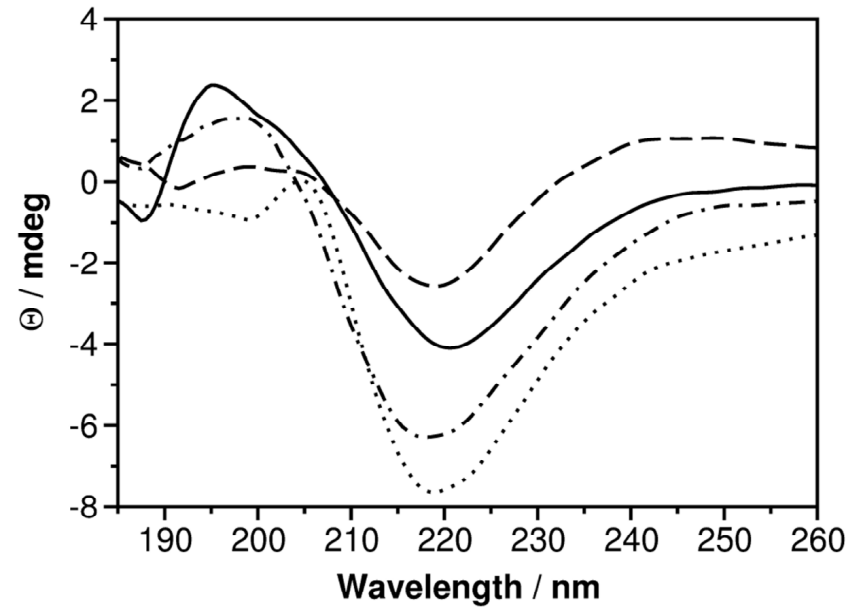

Figure 5. ECD spectra of PMS-trypsin in $60 \%(\mathrm{v} / \mathrm{v})$ ethanol $/ 10 \mathrm{mM}$ PBS $(\mathrm{pH}=7.0)$ in the absence (solid line, dashed line) and in the presence of 50-fold diluted Egri bikavér (dotted-dashed line, dotted line). The sample was set either in the middle of the sample compartment (solid line, dashed-dotted line), or next to the detector (dashed line, dotted line). PMS-trypsin concentration was 0.15 $\mathrm{mg} / \mathrm{mL}$. by the addition of diluted red wine. Conversely, ECD spectra recorded in different cuvette positions suggest, that addition of red wine do not arrest transition from native to $\beta$-sheet structure, but it may inhibit intermolecular associations and the formation of large aggregates.

\section{CONCLUSIONS}

Results of the present in vitro study demonstrated that red wines inhibit the aggregation of PMS-trypsin in $60 \%(\mathrm{v} / \mathrm{v})$ ethanol/10 mM PBS $(\mathrm{pH}=7.0)$ in a dose-dependent manner. The inhibitory effect was found to correlate with the amount of natural phenolic and polyphenolic substances contained in red wines. Although further studies are needed to verify direct applicability of red wine or its active components, our results suggest that moderate red wine consumption may constitute a part of a preventive dietary strategy against amyloidogenic diseases of the gastrointestinal tract. Among the examined red wines Egri bikavér demonstrated the strongest inhibitory effect on trypsin fibril formation.

\section{LIST OF ABBREVIATIONS}

$\begin{array}{lll}\mathrm{BAEE} & =N \text {-benzoyl-L-arginine ethyl ester } \\ \mathrm{ECD} & =\text { electronic circular dichroism } \\ \mathrm{CR} & =\text { Congo red } \\ \mathrm{GAE} & \quad \text { gallic acid equivalent } \\ \mathrm{PBS} & = & \text { phosphate buffered saline } \\ \mathrm{PMSF} & = & \text { phenylmethylsulfonyl fluoride }\end{array}$

\section{CONFLICT OF INTEREST}

The authors confirm that this article content has no conflicts of interest.

\section{ACKNOWLEDGMENTS}

Ph. D. scholarship was provided for P. B. K. by the Tempus Public Foundation through their 'Stipendium Hun- 
garicum' program. The research of A. B. was supported by the János Bolyai Research Scholarship of the Hungarian Academy of Sciences.

\section{REFERENCES}

[1] Simon, L.M.; Laczkó, I.; Demcsák, A.; Tóth, D.; Kotormán, M.; Fülöp L. The formation of amyloid-like fibrils of a-chymotrypsin in different aqueous organic solvents. Protein Pept. Lett., 2012, 19(5), 544-550.

[2] Dorta-Estremera, S.M.; Li, J.; Cao, W. (2013) Rapid generation of amyloid from native proteins in vitro. J. Vis. Exp., 2013, (82), 50869. doi, 10.3791/50869.

[3] Dobson, C.M. Protein folding and misfolding._Nature, 2003, 426(6968), 884-890.

[4] Stefani, M.; Rigacci, S. Protein folding and aggregation into amyloid: the interference by natural phenolic compounds. Int. J. Mol. Sci., 2013, 14(6), 12411-12457.

[5] Shariatizi, S.; Meratan, A.A.; Ghasemi, A.; Nemat-Gorgani, M. Inhibition of amyloid fibrillation and cytotoxicity of lysozyme fibrillation products by polyphenols. Int. J. Biol. Macromol., 2015, 80, 95-106.

[6] Jayamani, J.; Shanmugam, G. Gallic acid, one of the components in many plant tissues, is a potential inhibitor for insulin amyloid fibril formation. Eur. J. Med. Chem., 2014, 85, 352-358.

[7] Karunaweera, N.; Raju, R.; Gyengesi, E.; Münch G. Plant polyphenols as inhibitors of $\mathrm{NF}-\kappa \mathrm{B}$ induced cytokine production-a potential anti-inflammatory treatment for Alzheimer's disease? Front Mol. Neurosci., 2015, 1(8), 16-24.

[8] Basli, A.; Soulet, S.; Chaher, N.; Mérillon, J.M.; Chibane, M.; Monti, J.P.; Richard, T. Wine polyphenols: potential agents in neuroprotection. Oxid. Med. Cell Longev., 2012, 2012:805762. doi, $10.1155 / 2012 / 805762$.

[9] Feng, Y.; Wang, X.P.; Yang, S.G.; Wang, Y.J.; Zhang, X.; Du, X.T.; Sun, X.X.; Zhao, M.; Huang, L.; Liu, R.T. Resveratrol inhibits beta-amyloid oligomeric cytotoxicity but does not prevent oligomer formation. Neurotoxicology, 2009, 30(6), 986-995.

[10] Evers, F.; Jeworrek, C.; Tiemeyer, S.; Weise, K.; Sellin, D.; Paulus, M.; Struth, B.; Tolan, M.; Winter, R. Elucidating the mechanism of lipid membrane-induced IAPP fibrillogenesis and its inhibition by the red wine compound resveratrol: a synchrotron X-ray reflectivity study. J. Am. Chem. Soc., 2009, 131(27), 9516-9521.

[11] Sneideris, T.; Baranauskiene, L.; Cannon, J.G.; Rutkiene, R.; Meskys, R.; Smirnovas, V. Looking for a generic inhibitor of amyloid-like fibril formation among flavone derivatives. PeerJ, 2015, 3, e1271.

[12] Porzoor, A.; Alford, B.; Hügel, H.M.; Grando, D.; Caine, J.; Macreadie, I. Anti-amyloidogenic properties of some phenolic compounds. Biomolecules, 2015, 5(2), 505-527.

[13] Porat, Y.; Abramowitz, A.; Gazit, E. Inhibition of amyloid fibril formation by polyphenols: structural similarity and aromatic inter- actions as a common inhibition mechanism. Chem. Biol. Drug Des., 2006, 67(1), 27-37.

[14] Bhat, W.F.; Bhat, S.A.; Bano, B. Evaluation of polyphenols as possible therapeutics for amyloidoses: Comparative analysis of Kaempferol and Catechin. Int. J. Biol. Macromol., 2015, 81, 60-68.

[15] Shoval, H.; Lichtenberg, D.; Gazit, E. The molecular mechanisms of the anti-amyloid effects of phenols. Amyloid, 2007, 14(1), 7387.

[16] Ghosh, S.; Pandey, N.K.; Dasgupta, S. (-)-Epicatechin gallate prevents alkali-salt mediated fibrillogenesis of hen egg white lysozyme. Int. J. Biol. Macromol., 2013, 54, 90-98.

[17] Bhattacharya, S.; Pandey, N.K.; Roy, A.; Dasgupta, S. Effect of $(-)$-epigallocatechin gallate on the fibrillation of human serum albumin. Int. J. Biol. Macromol., 2014, 70, 312-319.

[18] Lakey-Beitia, J.; Berrocal, R.; Rao, K.S.; Durant, A.A. Polyphenols as therapeutic molecules in Alzheimer's disease through modulating amyloid pathways. Mol. Neurobiol., 2015, 51(2), 466-479.

[19] Ngoungoure, V.L.; Schluesener, J.; Moundipa, P.F.; Schluesener, H. Natural polyphenols binding to amyloid: a broad class of compounds to treat different human amyloid diseases. Mol. Nutr. Food Res., 2015, 59(1), 8-20.

[20] Berhanu, W.M.; Masunov, A.E. Atomistic mechanism of polyphenol amyloid aggregation inhibitors: molecular dynamics study of Curcumin, Exifone, and Myricetin interaction with the segment of tau peptide oligomer. J. Biomol. Struct. Dyn., 2015, 33(7), 13991411.

[21] Yamada, M.; Ono, K.; Hamaguchi, T.; Noguchi-Shinohara, M. Natural phenolic compounds as therapeutic and preventive agents for cerebral amyloidosis. Adv. Exp. Med. Biol., 2015, 863, 79-94.

[22] Sgarbossa, A. Natural biomolecules and protein aggregation: emerging strategies against amyloidogenesis. Int. J. Mol. Sci., 2012, 13(12), 17121-17137.

[23] Clardy, J.; Walsh, C._Lessons from natural molecules. Nature, 2004, 432(7019), 829-837.

[24] Kotormán, M.; Simon, L.M.; Borics, A.; Szabó, M.R.; Szabó, K.; Szögi, T.; Fülöp, L. Amyloid-like fibril formation by trypsin in aqueous ethanol. Inhibition of fibrillation by PEG. Protein Pept. Lett., 2015, 22(12), 1104-1110.

[25] Schwert, G.W.; Takenaka, Y.A. spectrophotometric determination of trypsin and chymotrypsin. Biochim. Biophys. Acta, 1955, 16, $570-575$.

[26] Waterhouse, A.L. Determination of Total Phenolics. In: Current Protocols in Food Analytical Chemistry; John Wiley and Sons, 2002; I1.1.1-I1.1.8.

[27] Wu, C.; Scott, J.; Shea, J.E. Binding of Congo red to amyloid protofibrils of the Alzheimer $\mathrm{A} \beta(9-40)$ peptide probed by molecular dynamics simulations. Biophys. J., 2012, 103(3), 550-557.

[28] Frid, P.; Anisimov, S.V.; Popovic, N. Congo red and protein aggregation in neurodegenerative diseases. Brain Res. Rev., 2007, 53(1), 135-160. 